\title{
Writing as Agency: \\ Can Arab Women's Post-Revolution Literature Become a Form of Empowerment?
}

\author{
Rana Elbowety*
}

Since 2011, the Arab region has been in political turmoil, with Arab women actively taking part in shaping the uprisings in their countries. Such political upheaval in the past few years has inevitably led to the emergence of a literature infused with politics, one that cannot help but partake in the political events that shape the country from which this literature emerges. Following the 2011 revolutions that swept through North Africa and Syria, several Arab women writers turned literature into a political arena. The post-revolutionary era in the Arab region witnessed a surge in Arab women's writings that engaged with the ongoing political discourse in their countries. Egyptian, Tunisian, and Syrian women writers, whose works did not necessarily engage with politics, found themselves active participants in uprisings that roiled in their countries, leading them to inevitably explore and revisit their countries' revolutions in writing, and to merge the personal with the political. This paper examines three works by three different Arab women writers who have turned to writing as a medium of empowerment and agency. By focusing on Judith Butler's notion of gender performativity and Hannah Arendt's concept of agency, the paper explores how Ahdaf Soueif's Cairo: My City, Our Revolution (2012), Amel Mokhtar's Dukhan al-Qasr (2013), and Samar Yazbek's A Woman in the Crossfire: Diaries of the Syrian Revolution (2012) respectively turn writing into a performative act that empowers Soueif, Mokhtar and Yazbek.

I have chosen to group these three works in particular for several reasons. First, all three works are written in three different genres: Soueif's narrative is a memoir, Mokhtar's is novel, and Yazbek's is a diary. The use of multiple genres by multiple authors serves to highlight that all different forms of writing serve as a medium that allows these women writers to engage with the national political discourse in each of their countries respectively and creates space for engaging with the national political discourse, resisting - at times - the official,

\footnotetext{
${ }^{*}$ Misr International University, Egypt.

Cairo Studies in English (2018): https://cse.journals.ekb.eg/
} 
state-dominated discourse, and producing a different, more personal version of political events.

The word 'gender' invites a barrage of interpretation since it no longer equates with sex as male or female. Gaining popularity in the 1970s, the term 'gender' emerged from under the umbrella of feminist studies in the West. Shortly after that, it found its way into cultural studies where its definition then took on new connotations pertaining to society and culture. Gender thus has become increasingly hard to define, and even hard to translate into languages where there is no direct linguistic equivalent. This ambiguity in defining the term extends to ambiguity in interpreting it. Is gender fixed? Is it unchanging in nature? What constitutes it? It becomes crucial then to understand what the term 'gender' means. For Judith Butler, gender is anything but fixed, which is why I turn to her interpretation of gender as performative in order to examine women's writing about revolutions in their countries as a production of performative acts that make room or carve new space for women to be empowered. To examine notions of power and agency, particularly in relation to speech, I rely on Hannah Arendt's The Human Condition (1958), with particular focus on the chapter titled 'Action'. The three texts I examine in this article invite readers to explore how writing has the potential to carve space for women's empowerment. Thus, my aim is to examine the process by which writing becomes an empowering medium where women, who have little place in the public sphere when it comes to the national discourse, can contribute to shaping this public sphere and find their voice. The three accounts of Arab uprisings that I tackle, namely Soueif's Cairo: My City, Our Revolution, Mokhtar's Dukhan al-Qasr (Palace Smoke), and Yazbek's A Woman in the Crossfire: Diaries of the Syrian Revolution are arguably performances that allow these women writers to 'produce' a written discourse that carves space for women's empowerment.

In the Arab world, there is little to no space for agency. On the ground, for agency empowerment to occur, there must be space where they can manifest. And in the reality of Arab women in post-revolutionary North Africa and Syria, there is little to no space for agency, hence no room for subjectivity to be formed and articulated. Therefore, empowerment for Arab women entails being allowed to use their voice and to be included politically and socially. The three texts I tackle are epitomes of a kind of writing that serves as an appropriate medium for women to simultaneously document their countries' uprisings and assert their agency, with the ultimate goal of empowering themselves. In light of the status quo in Arab countries in general, and in the case of women in particular, the medium of writing the political is arguably one of few virtual spaces where such empowerment can occur. 
In order to examine Judith Butler's argument that gender is performative, it is important to first understand the process of subjectivity formation from her perspective. Butler believes that the "I" is constituted, not situated by theoretical positions around it. These theoretical positions are the institutional practices that shape the "I", whether, or not, this is part of these practices. The "I" does not preside over these positions; it is rather these theoretical positions that preside over the "I". Yet this does not negate the power of the "I". The stances that an individual opposes, or excludes, shape that individual. Therefore, position shapes subjectivity. If one agrees with this conclusion, it is only natural then to realize that subjectivity is in a constant, ongoing process of formation; for if subjectivity is determined or fixed, an individual will no longer have agency. Butler thus argues that "the constituted character of the subject is the very precondition of its agency" (Butler 1992, 12). Therefore, the subject "is never fully constituted, but is subjected and produced time and again" (Butler 1992, 13). It is, as Butler calls it, "neither a ground nor a product, but the permanent possibility of a certain resignifying process" (13). The subject then remains a permanent possibility, a point towards which one perpetually travels.

Just as subjectivity is constituted and not inherent, and is constantly in motion, gender is a construct, as Butler explains in her seminal 1990 book Gender Trouble. To her, gender is one of the more fluid constituents of identity. It is not fixed, because it entails actions, and is thus quite different from the term 'sex' which has purely biological connotations. In one of her more seminal essays, "Performative Acts and Gender Constitution: An Essay in Phenomenology and Feminist Theory" (1998), Butler delineates how gender is constituted: "gender is in no way a stable identity or locus of agency from which various acts proceed; rather, it is an identity tenuously constituted in time - an identity instituted through a stylized repetition of acts" (519). She explains that gender then is the way "in which bodily gestures, movements, and enactments of various kinds constitute the illusion of an abiding gendered self' (Butler 1992, 13). Her argument thus is not whether, or not, we put on a show or a performance; it is what form that performance will take. This contention thus "is useful in considering language and actions as 'effecting/doing' consequences," as Butler argues (qtd. in Mazloum 2015, 208). It is possible then to assert that both actions and speech contribute to the constitution of identity as a whole, and subsequently, the constitution of gender identity. Writing thus can be seen as a natural performative act by Ahdaf Soueif, Amel Mokhtar, and Samar Yazbek in response to popular uprisings in Egypt, Tunisia, and Syria respectively. It is an act that has the capacity to carve space for women's empowerment.

On one level, the act of writing itself is performative, just as gender is to Butler, in the sense that it is a product of a process that not only requires time to 
complete, but is also repeated consistently or "tenuously constituted in time", which echoes Butler's view of gender identity (1988, 519). Furthermore, whereas gender is "instituted through a stylized repetition of acts" (Butler 1988, 519; emphasis not mine), writing also is merely a series of stylized repetition of the act of writing. Writing becomes performative in the sense that it turns to a virtual space where the writer's subjectivity is given room to take form. It is a process that reveals stances, opinions, reflections, and aspirations, and, hence, contributes to the formation of one's subjectivity. By taking part in the uprisings in their countries, Soueif, Mokhtar, and Yazbek have asserted that as women, their subjectivity continues to change constantly, in their case through the transition to the political in writing, and that the act these three writers perform, namely writing and - in the process - empowering themselves, is what constructs their gender, and not the other way around.

Hannah Arendt argues that "action is constitutive of the individual as an agent" (Allen 2002, 137). Action is essential to Arendt: "A life without speech and without action, on the other hand ... is literally dead to the world; it has ceased to be a human life" $(1958,176)$. For Arendt, "To act, in its most general sense means to take the initiative, to begin ... to set something into motion" (1958, 177). An individual is what she calls a "beginner," someone who sets things in motion. This inevitably establishes a link between action and agency, and - in turn - subjectivity and identity. "In acting and speaking, men show who they are, reveal actively their unique personal identities and thus make their appearance in the human world" (Arendt 1958, 179). As the political sphere becomes decidedly more male-dominated at times of national crises, women struggle to find space for them to occupy, hence the turn to writing. 'Writing a revolution' is first and foremost a means of documentation and preservation, but it has also grown to be a sphere where women can carve space for themselves, both to participate and to empower themselves. Writing on power in The Human Condition, Arendt describes it as existing "only in its actualization ... [p]ower is actualized only where word and deed have not parted company ... where words are not used to veil intentions but to disclose reality" $(1958,200)$.

If we examine the 2011 uprisings for what they were, we would find Arendt's definition of power is applicable in full throttle. What brought those uprisings to life in the first place is the people's 'action', their decision to come together. And what drove those uprisings forward is the power generated or rather 'actualized' - to use Arendt's terms - when masses took to the streets to protest against their regimes. Power has been actualized then, and it has been actualized in writing as well because that writing was used to 'disclose reality,' to use Arendt's words. Women were active participants, taking to the streets, chanting against corrupt 
regimes, calling for the toppling of presidents. They were essential to maintain the power generated and needed to topple a country's leader.

Yet, when the public sphere or the public space began to be gradually constricted, women found another sphere to continue their resistance, to voice their thoughts, and to act through writing. As Leo J. Penta puts it, "While it is apparent and recognized that speech and action form an inseparable pair in Arendt's work, this same link between speech and power is rarely recognized" $(1996,211)$. Here, I interpret the word 'speech' in a non-literal sense where it refers to the use of language in a general manner, be it spoken or written. Spoken language is a primary form of protest. When an individual voices objection to, or protests against, one thing or another, they are speaking their mind. Similarly, when people collectively protest, they take to the street and 'chant'. Speech thus is strongly linked to power. However, when one medium of expression closes, the individual seeks another. In the case of the three women writers I focus on in this article, writing was the alternative to the spoken word. Thus, through 'writing the revolution,' the three women writers in question have invariably found a medium that empowered them. Writing was the voice they needed to speak to the rest of the world; it was the action needed for their empowerment. Leo J. Penta characterizes "the relationship between action and power in Arendt as correlative rather subsidiary" $(1996,211)$. Arendt's notion of power is tied to action, and action, she argues, is inextricably linked to speech: "Speechless action ... would no longer be action because there would no longer be an actor, and the actor, the doer of the deeds, is possibly only if he is at the same time the speaker of words" (Arendt 1958, 178-9). As Amy Allen puts it, "power [for Arendt] is a condition of possibility for agency ... it is [also] a condition of possibility for subjectivity itself' $(2002,138)$.

Ahdaf Soueif, a prominent Egyptian novelist as well as a political commentator, published her 2012 book Cairo: My City, Our Revolution, a testimony to the first 18 days of the 2011 Egyptian revolution, which culminated in the ouster of longstanding president Mohamed Hosni Mubarak. Soueif's novel is a testimony, closer in nature to a documentary than to a work of literature, or more specifically of fiction. The work primarily focuses on the city of Cairo, yet it also explores firsthand the feelings Soueif experienced during those 18 days as she took to the streets and was a part of the whole that contributed to political change. By exploring her intimate relationship with Cairo, Soueif conveys to the reader not only how the events of the revolution unfolded over a period of time, but how her own engagement in these events manages to merge the personal with the political. It is a firsthand account of a woman's involvement in the political scene in Tahrir square as it unraveled. 
On the other hand, Amel Mokhtar's Dukhan al-Qasr is not a testimony so much as a novel infused with personal autobiographical entries in the authorial voice. For example, she starts one entry with a direct statement saying: "I, the writer Amel Mokhtar, ..." (my translation) and then she proceeds to spill her stream of thoughts on paper. Thus, the fictional part of the narrative intertwines with such autobiographical entries. The novel revolves around the buildup of events in several parallel plots which have different narrators, with a fascinating and unusual interaction in the middle between the novelist and her characters who stage a sit-in to demand that she pays attention to them as figments of her creation. Unlike Soueif, who has for years been engaged in the political scene in Egypt although she lived in the UK, Mokhtar's body of literary works did not touch upon politics at all before she wrote Dukhan al-Qasr. The novel thus acts as an insight into the inner workings of Mokhtar's mind during the days leading up to the Tunisian uprising against former president Zine El Abidine Ben Ali. Mokhtar's decision to delve into politics subverts expectations and highlights the then-felt need for shattering gender norms; thus asserting once more that gender is not inherent, that it is made up of an individual's acts, which in turn consolidates Butler's argument on performativity of gender and, in the process, illustrates the capacity of writing to create space for empowerment.

Samar Yazbek's A Woman in the Crossfire: Diaries of the Syrian Revolution is primarily a diary comprised of reflections on her experiences amid four turbulent months in 2011 during Syria's uprising against Bashar al-Assad's regime. The book takes the reader through a journey of Yazbek and her daughter's struggle to survive as her sense of insecurity gradually surmounts after she attracts the regime's unwanted attention for her political activism and outspokenness. Yazbek's occupation as a journalist gives her an excellent vantage point to write entries that are not only poetic, but also solidly journalistic as they provide a remarkable viewpoint of the Syrian uprising as it began.

Soueif is a novelist, but Cairo: My City, Our Revolution is not a novel. "Before 2011, Soueif's novels, like other Egyptian writers, reflected the overlapping preoccupation with feminist, social and national issues" (Mazloum 2015, 212). What is different in Cairo: My City, Our Revolution, which is more of an account of Cairo and the 2011 revolution than a novel, is the political dimension. Unlike earlier works where dislocation was a feature, this work, which merges the documentary and the literary, focuses solely on Cairo from two angles: a personal narrative exploring the memory and a collective one exploring the shared experience of people during the first 18 days of the 2011 revolution that ousted former president Hosni Mubarak. The city is reclaimed through the eyes of Soueif, who at once merges the personal with the political. 
It is her city that she talks about; hers in the sense that we as readers get to see Cairo as remembered through her personal stream of memories. Yet it is our revolution [the Egyptians' revolution], with an emphasis on the collective political experience. The act of writing itself is a form of documenting the Cairo of January and February 2011, and of preserving and protecting it from loss and mutation. As Mazloum illustrates: "It is also interesting to note that when Soueif writes about the January revolution, she writes a memoir rather than a novel where her 'I' is completely reintegrated with a newly regained Egyptian collective" (Mazloum 2015, 213). By "writing the revolution," by using memoir as a particular form of writing that merges the autobiographical and the documentary, Soueif is warding off collective forgetfulness and ensuring the preservation of a text that can counter - through its capacity to paint the Cairo of early 2011 - potential mutations by the state, or the hegemonic power in play.

One of the ways in which subjectivity is enunciated in the text is the interchange between the 'I' and the 'we'. From the very first pages, Soueif introduces the reader to Cairo and to the early events of those first 18 days by demonstrating her involvement in the events. Yet the entries in the text constantly alternate between personal memories of her own childhood and life in Cairo and the events that occurred during those 18 days. It is important to note that while Soueif does not assert women's role in a straightforward manner in her text, she constantly refers to unity beyond the use of the pronoun 'we'. Her narration demonstrates a sense of cohesion among the protesters. The act of writing to reclaim the city and the revolution is a statement not only of Soueif's, but of all women's part in shaping this event. And though it is a documentary account written from a personal angle, it transcends the boundaries of the personal and acts as a testament, first, to women's role in the events that changed their country, and, second, to the capacity of the act of writing such a text to become a tool to empower.

Soueif demonstrates the capacity of writing to become a constituent of gender performativity in her "stylized repetition" of the act itself (Butler 1988, 519; emphasis not mine), particularly because she not only published Cairo: My City, Our Revolution in 2012, but because she followed it with Cairo: Memoir of a City Transformed, in which she looks back on how the 2011 revolution transformed the city. The latter book also alternates between her own personal memories of the city from her childhood and ends with her focus on several shifts and turns that Cairo witnessed in its post-revolution years. Revisiting this Cairo highlights how Soueif's own gender identity is constituted in time as much as her act of writing indicates that gender is constituted in time. Soueif's act of taking part in and documenting, then revisiting, the revolution in writing also 
demonstrates Arendt's notion of actualized power which entails a merger between "word and deed," as Arendt puts it $(1958,200)$.

It is perhaps what Sherine Mazloum refers to as "Soueif"s interstitial position as a [woman] writer who has access to both western and eastern cultures" that propelled her to 'act' $(2015,212)$. After her participation in protests that took place in the first 18 days of the revolution, Soueif opted for writing her memoir and had it published in early 2012. When demonstrations dwindled due to crackdowns, arrests, forced disappearances, and the dangers of taking to the streets, Soueif used her position as a woman writer to document the revolution in writing. When the public sphere almost shut down, the alternative that opened up was writing. Accordingly, it is crucial to note the timing of the publication of the text, especially that Soueif acknowledges in an interview that her publisher asked her to write something on Cairo sometime before the revolution; so, it was in fact a commission. It was published in early 2012, right in the heart of the formation of a counter-revolution. Sameh Naguib writes, "After the Muslim Brotherhood's Freedom and Justice Party won the 2012 elections and began implementing Islamist policies, the army was forced to step in again to prevent the country from backsliding into authoritarianism" (2016, n. page).

For Soueif to have her text published in the middle of the counter-revolution is a means of grounding and documenting the events of those 18 days in the collective memory: "Insofar as one's identity as an actor is only fully realized in and through action in the public, political realm, and the public political realm is constituted by power, it turns out that, for Arendt, power is a condition for the possibility of (the full achievement of) agency" (Allen 2002, 138). It can thus be argued that publishing the manuscript amid Egypt's counter-revolution is one form of communicative power that allows Soueif to claim agency as a woman. Soueif's continuous use of the pronoun 'we' reflects and consolidates an image of unity and cohesion in the national fabric. The significance of this type of writing stems not only from the fact that it preserves and perpetrates an image of Cairenes (and implicitly of all Egyptians) as they were in 2011, which in turn ensures that no matter how reality changes in coming months and years, but that this image will remain unchanged, which asserts how Soueif has carved space where she can immortalize the revolution and, in the process, emphasize her capacity to assert her agency.

Tunisia was the first Arab country that "protested against corruption, poverty, and political repression and forced [Tunisian] Pres. Zine al-Abidine Ben Ali to step down in January 2011" in what was dubbed the Jasmine Revolution ("Jasmine Revolution: Tunisian History", n. page, para. 1). Tunisians revolted against political corruption and oppression, and women were a major force in 
that revolt. When the country was in the grip of Islamist rule after the hopeful period that followed the ouster of Ben Ali, many women grew "anxious regarding the present and future status of women's rights under Islamist rule" (Mamelouk 2015, 103). It is no wonder then that Mokhtar's novel is indicative of the author's shift to the political. Mokhtar started writing her novel in September 2010 and had to pause for several months when the revolution erupted. Yet oddly enough, in an interview with Mokhtar, she explained that incorporating politics into the novel was not a choice, that she was, in a way, 'coerced' into it as she started writing the novel months before the Tunisian revolution erupted on January 14, 2011. In an interview with her, Mokhtar said she did not choose to write about the revolution, and if she had been given a choice, she would not have done it. She added that she got involved in writing this novel, which was like a dish she had started cooking and had to finish ("Alriwa'iyya Amel Mokhtar", para. 4). The word 'coerced' here is used to imply that Mokhtar found - after the revolution - that she could not help but write about the revolution, make room for it in her narrative. The novel then probably would have never infused the literary with the political, were it not for the revolution. This allows readers to grasp not only the impact of the revolution on Mokhtar's writing as a woman, but on her choice to bring politics into her writing as a means of empowerment through writing as a performative act.

The novel, published in 2013, revolves around several main characters who tell their own stories. Each narrator comes from a different socio-economic class, with an emphasis on the only female narrator among them, Nour al-Katib, who happens to be a journalist. Later, when the author encroaches on the literary space (the characters' space) by writing in the first person her thoughts and fears for the future of the Tunisian revolution, the characters protest against her interruption of their narrative. In a chapter titled "Mahdi's sit-in", the characters decide to hold an "i'tisam," a sit-in, to protest against this interruption: "What is that? I try to write, but the letters won't merge together ... I wanted to make room for Mahdi, Nour's son, to speak to us about his worlds and the worlds of his young friends and their relation to the revolution" (Mokhtar 2013, 103; my translation). As Mokhtar finds she cannot write, Mahdi uses this opportunity to his advantage and the following words appear on her computer screen: "I've used the time you were busy rearranging events to ask you calmly to make room for me to talk. You have oppressed my character and prevented me from talking through all those pages. Give me this chance now or I will shut up forever and will never speak for you again" (Mokhtar 2013, 103-4; my translation). When Mokhtar reconsiders her choice of Mahdi's character, Mahdi adds: 
"Why don't you, my madam the writer, use rubber bullets like Hamadi Jibali's government did with demonstrators in [the town of] Siliana? What is the difference between you and that fascist government that does not understand dialogue? Just like that, you think of replacing me with another character? Why didn't you think of initiating dialogue with me? Why do you continue to oppress me and I only asked for the right to speak?" (2013, 104; my translation).

What is noteworthy here is that Mahdi's words are reminiscent of the Tunisians' revolt against Ben Ali's regime. Mokhtar is exercising her role as a writer to voice her people's thoughts through Mahdi, who, as a character supposedly under the complete control of Mokhtar, the author, resists and asks for his requests to be heard, echoing what Tunisians have asked of their government. Like Mahdi, Tunisians do not want to be subdued, their voice remaining unheard. Mahdi becomes a symbol for all Tunisians as they seek liberation from the state of voicelessness they have endured. In the end, Mokhtar chooses to listen to her characters and responds to their political protest positively (Mamelouk 2015, 110).

While all characters are the product of Mokhtar's literary imagination, Mokhtar seems to be using Nour's character in particular as a mouthpiece for herself, allowing her room for voicing thoughts and concerns, political and otherwise, in a work that is purely literary in nature. She empowers Nour in more ways than one: First, she allocates her a relatively large space in the novel, compared to other characters. Second, she empowers her by depicting her as a journalist. It is interesting here to note that the writer gave her only female character a job that is based on writing, and not just any writing, but journalistic writing in particular (which entails owning a sense of curiosity, a love for investigation, and a mind that always questions and seeks to find the truth). Thirdly, she empowers her on the level of the domestic household when she has her stand up to her abusive husband. This type of empowerment is not merely a sign of strength; it is a demonstration of the need to shatter gender stereotypes, a move to reinstate woman as equal to man, as an individual on par with her male counterpart.

In an interview with Douja Mamelouk, Mokhtar says: "I do not accept that Tunisia should develop into a massive prison surrounded by fallacies and Wahhabi religious thinking that threaten to destroy the accomplishments Tunisia has achieved during half a century as a modern Arab Muslim republic" (qtd. in Mamelouk 2015, 100). This embodies a shift from political silence to political articulation; the utterance is not merely a statement, rather it is a performance, 
one that gives voice to women's fears regarding their rights under the then-new regime which succeeded Ben Ali's rule. In the novel itself, the last line sees Nour - whom Mokhtar uses as her mouthpiece - uttering the following with pride: "I am a Tunisian woman" (Mokhtar 2013, 179; my translation). In choosing to end her novel with these words, it is important to note the emphasis on the word 'woman', hence on gender. It is not just that Nour/Mokhtar asserts her nationality as a Tunisian; it is this articulation of gender and this pride in the enunciation that turn writing into an act of empowerment.

In the words of Douja Mamelouk, Mokhtar has switched "from political silence to political engagement" (Mamelouk 2015, 100). Her engagement with politics in her narrative through her main characters and her own voice as the author and through infusing the narrative with political statements is a performative act that makes room for Mokhtar to highlight women's role in postrevolutionary Tunisia and, actively seeks to assert their presence in the political arena: "Mokhtar has shifted in her writings from discussing the social sexual taboos of Tunisia before the Revolution to revealing the innovative political spaces born after the Revolution" (Mamelouk 2015, 114). As the novel marks Mokhtar's shift to the inclusion of politics into her writing, it brings to mind Arendt's notion of power as a condition for agency. Thus, the act of writing the novel can be seen as a tool for empowerment by asserting its author's agency.

At one point in the narrative, during one of her autobiographical entries, Mokhtar, in her capacity as the author, writes that her own self-censorship "shackles the act of freedom which must accompany the act of writing" (Mokhtar 2013, 55; my emphasis; my translation). Mokhtar confesses that her self-censorship may have been a response to her fear that the novel would not be published or circulated: "Perhaps my self-censorship stemmed from the depths of my fear that the novel would be prohibited from circulation, and I launched myself into writing it with a mad desire to find fresh air to breathe amid the suffocation most Tunisians and I had lived in for years" (Mokhtar 2013, 56; my translation). Here Mokhtar reveals the solid link between the sense of suffocation she and Tunisians at large experienced, and the resulting resolve to write as a means of freeing oneself and creating a venue for self-expression. Thus, writing fulfills Arendt's condition of power, enabling Mokhtar to have agency.

Samar Yazbek's A Woman in the Crossfire: Diaries of the Syrian Revolution (2012), presents itself as a log or diaries that chronicle events that came to occur in Syria between March 2011 and July 2011, as seen through the eyes of Yazbek herself: a journalist, an emerging writer, a feminist, and a cultural activist who voiced opposition to Bashar al-Assad's regime and took part in the 2011 Syrian uprising. As Roger Bromley writes, "Apart from ending the culture of fear, overcoming humiliation and restoring dignity, the Arab Spring initially also 
opened up spaces and time for narrative, enabling and empowering cultural forms to be recovered, restored and, of course, invented, with writers once more being able to renew their function of narrating the truth to power" $(2013,223)$.

In the book's Foreword, Rafik Schami - a Syrian author, storyteller, and critic - makes several references to two actions that Yazbek did: active participation, and documentation. His foreword highlights the connection between the two actions, with an emphasis on the "active" role Yazbek played:

"For one hundred days, the Syrian writer and filmmaker documented the revolution in her country - up close and personal. Not only that: she actively took part in it. And whenever the situation allowed it she wrote down what she had experienced in the hours and days before, what she felt and thought; all in impressive, powerful language." (2013, vi; my emphasis)

Schami's choice of words sheds light on a link between an individual's experience, or action, on the one hand, and the act of writing or documentation on the other. Yazbek's active participation in the revolution, her stance as an "active witness" as Schami calls her, has not only been mirrored in her writing; it seems that writing was, for Yazbek, the continuation of that action.

As a woman, Yazbek came from a respected, well-to-do Alawite family in Jableh, Syria. According to Schami, "Her family, and the connections they afforded her, allowed her a degree of freedom not enjoyed by others but she was not blinded by it" (Schami 2013, vii). To her family, Yazbek became a disappointment when she decided to "declare her solidarity for Syria's oppressed" (Schami 2013, vii). And well before the Syrian revolution began, Yazbek had already joined the protest movement and positioned herself as an oppositionist to Assad's regime. Yazbek is conscious of her role as a writer: "Somebody has to smash the narrative of this criminal regime with the truth of the revolution. This is a revolution and not a sectarian war, and my voice as a writer and a journalist must come out in support of the uprising, no matter what the cost" (Yazbek 2012, 230). Her narrative at once captures the public and private struggle of her people and herself. Her choice of the title 'A Woman in the Crossfire' points literally and figuratively to her being caught in the crossfire (Bromley 2013, 228). At points, she refers to herself as living in "a real-life novel" and illustrates how "writing toughens [her] up against the hardships of life" (Yazbek 2012, 90).

While Yazbek's book is an attempt to come to terms with the brutality of the regime, it is also her way of resisting the official narrative. By documenting the 
unraveling of the revolution against Asaad's regime, Yazbek offers insight into the stance of the opposition and at the same time asserts her agency through the act of writing. In the last entry in the book, Yazbek states her resolve to turn these diaries into a book: "Writing these last words I resolve not to return to these pages until I can turn my diary into a book. I'd never be able to do that in Syria; if I could, I would just stay" $(2012,258)$. It is as though by documenting and highlighting what she and other figures of opposition have been through during the first four months of the Syrian uprising, she recognizes the latent power that publishing has not only in giving voice to her people, but, by extension, empowering her and all Syrians. On Soueif and Yazbek together, Bromley writes that "what they produce is a narrative memory, storying the present and encoding a potential future: imprinting and scripting publicly available signs, symbols and scenes supplemented by the subjective category of the witnessing activist" (2013, 223; emphasis not mine).

Combining Butler's understanding of gender as performative and Arendt's focus of the relationship between power, agency, and speech, it becomes clear that writing as a performative act is a means of gaining power. The act of documenting what she and others have endured proves that Yazbek is a 'beginner', which is Arendt's word to describe someone who sets things in motion. Accordingly, Yazbek sets things in motion, or becomes a 'beginner', when she decides to write, and later publish, her manuscript. As Arendt demonstrates, "[i]n acting and speaking, men show who they are, reveal actively their unique personal identities" $(1958,179)$. The connection Arendt makes between action/speech and identity being on display serves to highlight how gender identity is constructed based on actions. In Yazbek's case, the decision to document the revolution and the hazards many Syrians suffered, and later to publish what she has written or compiled, has contributed to the construction of her gender identity, allowing her a space to voice her experience and, thus, to empower herself.

The works are examined as spaces of enunciation where the three women writers engage in a performance, namely writing, that renegotiates their subjectivity and casts them as active participants in the political scene in their countries. Whereas Soueif is more fixated on this unity or merger between the personal and the collective, Mokhtar signals the transition of political silence to political articulation, while Yazbek's ultimate goal is to document events and capture the voice of the opposition as a means of empowering both herself and her people. The paper traces instances where the women writers assert their shift towards the political in writing, consolidating the view that gender is constructed through writing as a performative act in the post-2011 era, and ultimately asserting their role as active agents who not only advocate change in the region, 
but highlight women's capacity to break away from the domestic sphere and participate in the public and political spheres. This goes to show the capacity writing has at certain, defining moments; a capacity to be explored and used as a medium for women's empowerment. Allowing a space for the formation of subjectivity ensures agency which in turn ensures empowerment. 'If there is no space for subjectivity' is then a synonym for 'no room for empowerment'. Thus, the act of 'writing the revolution', of documenting it, is ultimately an act of empowerment on an individual level and on a more collective one.

By resorting to writing, Soueif, Mokhtar, and Yazbek have sought empowerment through writing as an extension of the power they experienced as part of the collective uprisings in Egypt, Tunisia, and Syria respectively. When the public sphere began to shrink, with crackdowns on the opposition movements and the limits imposed on freedom of expression (particularly the restrictions on mass gatherings and the dangers they entailed), they sought to recreate the agency they were granted through the shared experience of revolt with their people through using writing as a means of resistance and empowerment. Simultaneously, the three writers have asserted their agency, and by extension their subjectivity, as women who can play a key role in contributing to the public sphere and asserting their agency, all while documenting their countries' revolts away from both the official state narrative and the maledominated narrative. The turn to 'writing the revolution' has thus opened up a new sphere for self-expression, agency, and empowerment for women in countries that sought to oppress their people and suppress the voice of resistance.

\section{Works Cited}

Allen, Amy. 2002. "Power, Subjectivity, and Agency: Between Arendt and Foucault." International Journal of Philosophical Studies 10, no. 2: 131-49, https://doi.org/10.1080/09672550210121432.

"Al-riwa'iyya Amel Mokhtar: laqad tawarrattu fi kitabat hadhihi al-riwaya" [Novelist Amel Mokhtar: I was trapped into writing this novel]. Essahafa. 25 April 2013.

http://www.essahafa.tn/wordpress/2013/04/25/الروائية_آمال_مختار_لقد-تورطت_في-كتاب. Arendt, Hannah. 1958. The Human Condition. Chicago: The University of Chicago Press.

Bromley, Roger. 2013. "Giving Memory a Future': Women, Writing, Revolution." Journal for Cultural Research 19, no. 2: 221-32, http://dx.doi.org/10.1080/14797585.2014.982914. 
Butler, Judith. 1992. "Contingent Foundations: Feminism and the Question of 'Postmodernism'." Feminists Theorize the Political. Edited by Judith Butler and Jean W. Scott. New York: Routledge.

-----. 1988. "Performative Acts and Gender Constitution: An Essay in Phenomenology and Feminist Theory." Theatre Journal 40, no. 4 (Dec.): 519-31, http://www.jstor.org/stable/3207893.

"Jasmine Revolution: Tunisian History." Encyclopaedia Britannica. 2 May 2018. https://www.britannica.com/event/Jasmine-Revolution

Mamelouk, Douja. 2015. "New National Discourses: Tunisian Women Write the Revolution." Alif: Journal of Comparative Poetics 35: 100-22, http://www.jstor.org/stable/24772813.

Mazloum, Sherine Fouad. 2015. "To write/to revolt: Egyptian women novelists writing the revolution." Journal for Cultural Research 19, no. 2: 207-20, https://doi.org/10.1080/14797585.2014.982923.

Mokhtar, Amel. 2013. Dukhan al-Qasr. Tunisia: Dar sahar 1-il-nashr.

Naguib, Sameh. "The Egyptian Counterrevolution". Jacobin. 3 November 2016. $<$ https://www.jacobinmag.com/2016/03/egypt-revolution-sisi-mubarakmuslim-brotherhood/>.

Schami, Rafik. 2012. "Foreword." A Woman in the Crossfire: Diaries of the Syrian Revolution. Translated by Max Weiss. London: Haus Publishing.

Soueif, Ahdaf. 2012. Cairo: My City, Our Revolution. London: Bloomsbury Publishing.

Soueif, Ahdaf. 2014. Cairo: Memoir of a City Transformed. London: Bloomsbury Publishing.

Yazbek, Samar. 2012. A Woman in the Crossfire: Diaries of the Syrian Revolution. Translated by Max Weiss. London: Haus Publishing. 